\title{
ACHIEVING GENDER EQUALITY THROUGH ELECTORAL PARTICIPATION OF WOMEN: A CASE STUDY OF 2005, 2010 AND 2015 ASSEMBLY ELECTIONS IN PATNA (INDIA)
}

\author{
Prerna Bharti ${ }^{* *}$ and Debjani Sarkar Ghose ${ }^{2}$ \\ 'Department of Geography, B.N College, Patna University, Patna-800001, Bihar, India \\ Department of Geography, Patna Women's College, Patna University, Patna- 800001, Bihar, India \\ *Corresponding author: prernasikka1993@gmail.com \\ Received: October 8 ${ }^{\text {th }}, 2020$ / Accepted: February 16 ${ }^{\text {th }}, 2021 /$ Published: April 1st, 2021 \\ https://DOl-10.24057/2071-9388-2020-168
}

\begin{abstract}
United Nations Sustainable Development Goal 5 advocates for the promotion of gender equality. It ensures women's full and effective participation and equal opportunities for leadership at all levels of decision making in politics. Females have a right to vote in elections, be elected to government office, serve on boards, and make their voices heard in any process that will ultimately affect them, their families, and their communities. Investing women's right to political participation is a necessary step to achieve global gender equality and democratic governance.

The paper aims to analyze the spatio- temporal participation of women in assembly elections of 2005, 2010 and 2015 in Patna District, to find out association between women's literacy levels and voting among women in the study area, and to identify motivational and situational constraints of women's participation in electoral process. For the present study, Patna district has been selected as the study area. The author adopted questionnaire survey and key informant interviews as a means for data collection. The growing participation of women in elections indicates a silent movement of women empowerment. It is found that there is a rising trend in the voting participation of women in the study area. Both literate and illiterate groups are conscious about their voting rights.
\end{abstract}

KEY WORDS: Vote, Gender Equality, Elections, Political participation, Empowerment

CITATION: Prerna Bharti and Debjani Sarkar Ghose (2021). Achieving Gender Equality Through Electoral Participation OfWomen: A Case Study Of 2005, 2010 And 2015 Assembly Elections In Patna (India). Geography, Environment, Sustainability, Vol.14, No 1, p. 132-141 https://DOl-10.24057/2071-9388-2020-168

Conflict of interests: The authors reported no potential conflict of interest.

\section{INTRODUCTION}

United Nations Sustainable Development Goal 5 advocates for the promotion of gender equality. This goal ensures women's full and effective participation and equal opportunities for leadership at all levels of decision making in politics. Practicing female's right to electoral participation is a necessary step to achieve global gender equality and democratic governance. Moreover, gender equality is necessary for a peaceful, harmonious and sustainable world (United Nations 2015). The Constitution of India guarantees Equality, Liberty and the right to participate in elections in its Preamble and under part III of the constitution (Kashyap 2019). Females have a right to vote in elections, be elected to government office, serve on boards, and make their voices heard in any process that will ultimately affect them, their families, and their communities (Kashyap 2019). Participation in the electioneering process is not only confined to voting rights but it is also related to representation, political activism, political consciousness and many more (Begum 2015). The electoral participation gives women the ability to analyze, organize, and mobilize for social change. In this paper, we analyse the women's participation in 2005, 2010 and 2015 Assembly Elections in my study area of Patna district, which is the capital of state of Bihar.
Niti Aayog, the policy think tank of Government of India has developed a Sustainable Development Goal (SDG) index assessing the performance all states of India in achieving the targets of Sustainable Development Goals. According to Niti Aayog's SDG Index 2019, the state of Bihar has been allocated a composite score of 50 out of 100 . In the fifth SDG-gender equality, Bihar scored 40 with the 17 th rank among all the 29 states, which is a below satisfactory performance. The indicators considered for SDG 5 include crimes against women, discrimination against women, and access to reproductive health schemes, as well as indicators showing women's economic and political empowerment and leadership.

An analysis of the representation levels of women in India's legislative bodies with other South Asian countries could be relevant to understand the levels of women's electoral participation. Data from the Inter-Parliamentary Union (2016) suggest higher levels for Nepal, Afghanistan and Pakistan, mainly due to reservations of seats for women. Lack of reservation of seats for Indian women in legislative assemblies, combined with several inherent societal and attitudinal factors, seems to act as a gender barrier and major obstacle to participation in electoral competitions and occupying legislative space on equal terms with men. Women's participation in elections is closely related to their level of empowerment (Khanna 2009). It is associated with 
the equal status of women, providing equal opportunity, and freedom for their development. The women empowerment is synonym with their increased role in the process of decision making. Few decades' back women would rarely go and vote. But fortunately now the scenario is changing and women are going in large numbers to participate in the electoral voting. This is a manifestation of a sustainable and just society.

However, it is necessary to understand that the problems, demands and political aspirations of women are different from men. Interestingly, from the last decade onwards, the political parties in the state of Bihar have incorporated the women-centric issues in their election manifesto such as liquor ban to stop domestic violence, free cycle scheme for every school going girl child, fifty per cent reservation for women in all the three tiers of Panchayati Raj Institutions (PRIs) in Bihar that was introduced in 2006. As a result, women leaders constitute about 54 percent of the total number of leaders elected to PRIs in the State. Out of the 1, 35,805 members across the PRIs in Bihar, 73,204 are women (Mamta 2011). The government is also playing a vital role in the empowerment of women by launching various schemes such as Anganwadi schemes in which women are engaged in early education, taking care of pregnant women, guidance and counseling to lactating mothers. Bihar is one of the states that have shown the progress in the women's political empowerment over the last decade (Mamta 2011).

There have been studies on the geography of election, voting behavior, political consciousness of voters in different parts of India. Dikshit and Giri (1983) examined the changing nature of spatial pattern of the parliamentary voting results in India from 1951 to 1982. Dikshit and Singh (1993) emanated friend and neighbor influence in Indian elections and said that as the distance of residence of voter's increases from the residence of candidates there is a decrease in political affirmation.

Hussain and Mir in 1984 identified the voting determinants for 1983 Assembly elections in Jammu and Kashmir. Dikshit and Singh (1993) emanated friend and neighbor influence in Indian elections and said that as the distance of residence of voter's increases from the residence of candidates there is a decrease in political affirmation.

The Further, the scholars have also assessed the women empowerment through their increased participation in political arena. Devi and Lakshmi (2005) studied political empowerment of women in Indian legislature and suggested that women representatives should form 'critical mass' so as to act as a pressure group in the legislature. They can also raise voice on crucial concern to women such as contraception, abortion, violence against women, gender discrimination, maternity leave, child care etc. M.M.S. Negi (2011) explained the voting attitude of women in Uttarakhand with special reference to Garhwal. According to him political awareness plays an important role in forming and shaping political attitudes such as those related to voting. Rajeshwari Deshpande (2004) has utilized National Election Studies data with a case study of Lok Sabha 2004 elections to have a detailed and, nuanced understanding about women's voting behavior, their participation and political attitude. Women's overwhelming participation in 2004 elections can be a pointer to strengthening women's role in politics for coming future. However, Rai (2017) underlines that while the women's voter participation is on rise reaching the highest female voter turnout in 2014 Lok Sabha elections, the continued under-representation of women in legislative bodies and power structure of political parties is worrisome. This can offset the gains of people-driven feminization of electoral politics of India. Kumar, et al. (2019) have explained the role of women selfhelp groups (SHGs) in increasing the political participation of women by assessing their participation in last election and making choice of voting independently without coercion from family members and others. However, the perspective on voting behavior and electoral participation of women are highly limited therefore this paper focuses upon women participation which has rarely been touched upon. The present paper is all about women participation in voting, who enjoy very little freedom of choice particularly the political choice. The patriarchal system is deeply rooted in the society of State (Datta and Preet 2012). The main question therefore remains to be the extent of political choice which the women of the state regardless of their age, social, culture and economic status enjoy. This may range to very little freedom, more freedom or no freedom of choice at all (Carole 2007). Nevertheless women in the state cast their vote but their participation very often became victim of the male control of the household. The objectives framed for the study - are to analyze the spatiotemporal participation of women in assembly elections of 2005, 2010 and 2015 in Patna District, to find out association between women's literacy levels and voting among women in the study area, and to identify motivational and situational constraints of women's participation in electoral process.

\section{Study Area}

Patna district has been selected as the study area. It is the capital of the state Bihar which makes it one of the important districts among the entire 38 districts of Bihar. The latitudinal and longitudinal extents of this district are $25^{\circ} 12^{\prime} \mathrm{N}$ to $25^{\circ} 44^{\prime} \mathrm{N}$ and $84^{\circ} 42^{\prime} \mathrm{E}$ to $86^{\circ} 4^{\prime} \mathrm{E}$ respectively. Patna district is also known as the heartland of Bihar, therefore, who rules Patna, commands the entire state of Bihar and even influences the national politics. There are fourteen assembly constituencies in Patna district. These are Maner, Bikram, Bankipur, Patna Sahib, Danapur, Kumhrar, Paliganj, Mokama, Digha, Fatuha, Masauri, Bankipur, Phulwari and Barh. The district is bounded by the river Son on the west, on the north by the Ganga River and on the south by Nalanda, Arwal and Jahanabad districts. On the east the district is bordered by Begusarai and partly by Lakhisarai. According to the 2011 census, Patna district has a population of $5,838,465$ in which the number of females is 2759953. The sex ratio is 897 females for every 1,000 males. Literacy rate is 70.68 percent in which female literacy rate is 61.96 percent.

\section{METHODOLOGY}

For a scientific and valid conclusion, pre field study, field study and post field study has been conducted. PreField Study includes library work, data collection from Election Commission of India, Census of India and the Department of Statistics, Govt. of Bihar. Newspapers (Times of India, The Hindu, Dainak Jagran and Hindustan) are also a part of pre field survey for the study. Data collection has been arranged in order for statistical and cartographic treatment. Questionnaire has been prepared on the basis of the pattern which has emerged after the processing of the data through statistical and cartographic methods.

In the field survey, primary data collection with the help of questionnaire regarding their voting perception has been done. Respondents have been selected with the help 


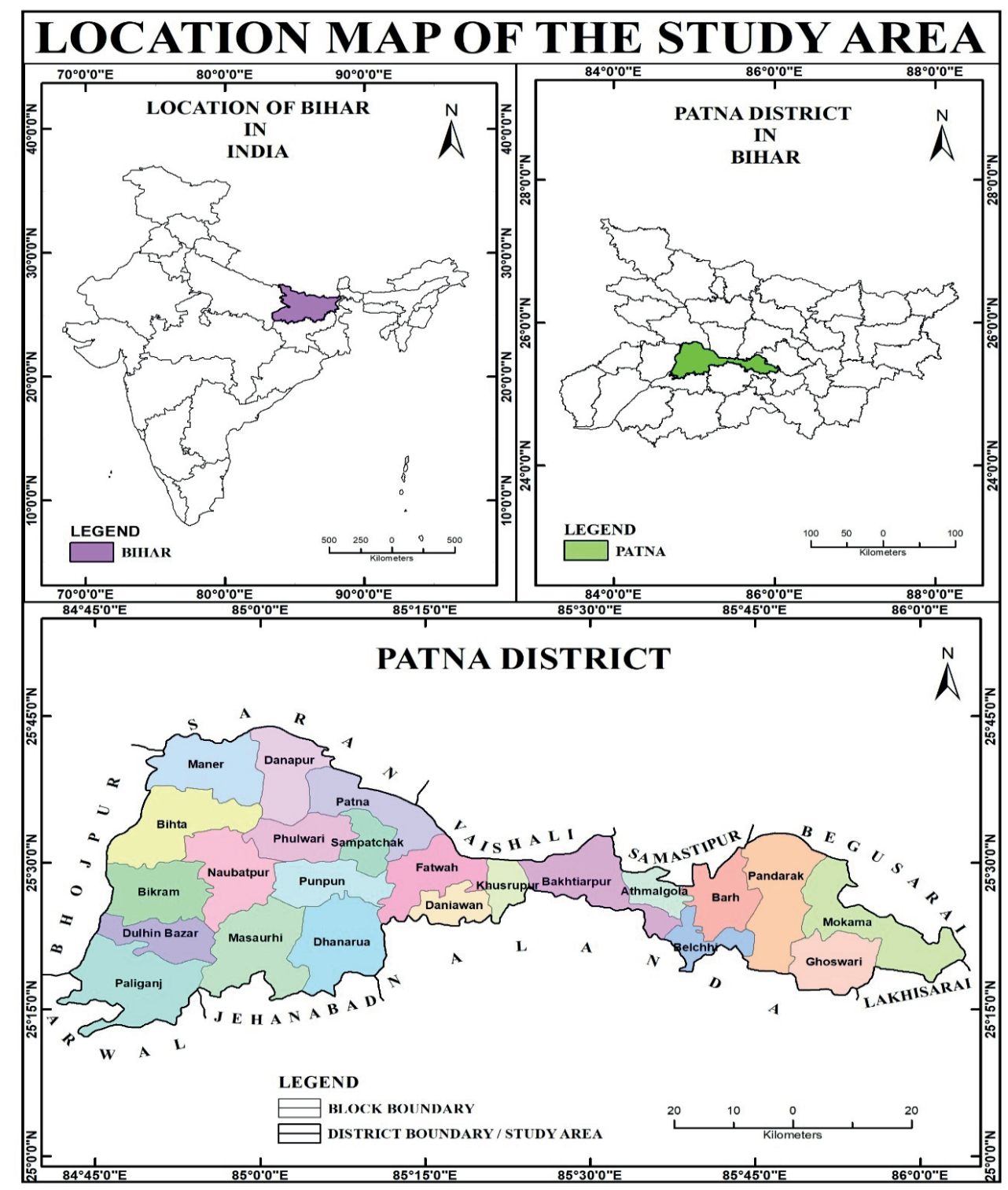

Fig. 1. Study area

of stratified random sampling technique. Tabulation and compilation of data collected through primary field survey has been done in order to find an appropriate result in post field survey. Statistical and mathematical treatment of data has been done and the result so obtained is represented by explanations and suitable diagrams using cartographic techniques.

A total of nine eighty six samples have been used in this study. 52.2 percent respondents are from rural areas, followed by 21.8 percent from semi-urban and 26.0 percent were urban residents. All of the fourteen assembly constituencies were visited and data were obtained through detailed questionnaire surveys.

Statistical analysis from February 2005 assembly election to 2015 assembly election had been done to find out mean, standard deviation, chi value and Bi-Variate Pearson correlation between male and female voters. The electoral data was collected from Election Commission of India.

\section{RESULTS AND DISCUSSIONS}

In this section, the Spatio- Temporal Participation of Women in Assembly Elections of 2005, 2010 and 2015 in Patna district is discussed. Palmer (1976) has pointed out that voting is the most common and important act of political participation. Increasing awareness among women voters about their rights began to influence the political scene (Fadia 2014) of the region. Electoral participation is a process in which the electorates participate in choosing their representatives. Voter's participation is measured as the percentage of registered voters in each constituency who actually exercise their voting right during the elections. Each voter has their own ideology, political orientation, judgment and expectations which pull them to vote for a particular candidate.

The recent participation level of women in the elections shows that there is an upsurge among women voters. 2014 General Elections saw women's voter turnout rising substantially to 65.3 percent from 55.82 percent in 2009. In 2015 female voter turnout rose to 68 percent tipping over that of men (Election Commission of India 2015). Women's active participation in electoral competitions is a valid indicator of the efficacious growth of democracy in any country of the world today (Nelson and Chowdhary 1994).

Bihar is one of the backward regions of the country, it is at the bottom of Niti Aayog's SDG Index, 2019 but there is remarkable growth of women in the electoral politics in terms of voting. The government regulated quotas and women centric political party manifestos such as 50 per cent reservation for women in the local body elections, scholarships for female students, free cycles and school uniform schemes for girls and a dedicated women police battalion in the state, 35 per cent reservation for women in state government jobs etc. motivates women to vote. Patna is one of the districts of state that have shown progress in women's political empowerment over the last decade. According to Election Commission report, 2010 
and 2015 women's turnout was more than men turnout in the previous two consecutive assembly elections of 2010, 2015 in Bihar. The women voter's turnout in the 2010 assembly election was 54.5 percent whereas the men's turnout was 51.1 percent. In the 2015 assembly election the women voter's turnout was 60.48 percent whereas men voter's turnout was 53.32 percent in Bihar (Election Commission of India 2015).

Patna district is the capital of the State and the administrative headquarter is located in this district. Therefore, the voter participation in the election in this region is important to gauge the mood of the voters and has several implications on the state elections. Das Gupta and Morris-jones (1975) stated that the voter's turnout is positively related to social development. It is largely beneficial for fighting socio- political gender parity. Adhikari (2005) said that voter's participation is a raison d'etre of election and no election is meaningful unless the people participate in it.

In Patna district, the participation of women voters is less than the male voters however there is a rising trend of women's voting participation.

\section{Voting Participation of Women in 2015 Assembly Election in} Patna District

Ali and Lin, 2013 said that «understanding why people vote is fundamental to the theory and practice of democracy». Participation in the voting process is an indication of political awareness and empowerment of the voters. Secondary data of Assembly Elections of 2005, 2010 and 2015 in Bihar, collected from Election Commission of India clearly revealed that except Mokama and Barh among all the assembly constituencies, the female voting participation is lower than the male participation. Secondly, rural women are voting more than their counterparts in the urban centers. Falcao, V, 2009, observed a similar pattern in his study that urban voters are most literate and aware about their rights but are less enthusiastic about voting.

Figure 2 shows that the highest percentage of voting among women in 2015 Assembly elections is in Bakhtiarpur i.e. 58 percent whereas the lowest percentage is in Kumhrar assembly constituency i.e. only 36 percent. Interestingly, Kumhrar constitutency is an urban constituency located within the limits of Patna Municipal Corporation. The assembly constituency in which total voting percentage is more than 60 percent is Bakhtiarpur, Fatuha and Maner. In Mokama, Barh, Patna Sahib, Danapur, Phulwari, Maner, Paliganj and Bikram assembly constituencies the total voting percentage is between 50 to 60 percent. Digha and Bakhtiarpur have 42.8 percent and 40 percent of total percentage of voting respectively.

Mukhyamantri Balika Cycle Yojana (launched by the Chief Minister of Bihar in 2006) under which around 4 million bicycles have been given to the school going girls in Bihar. This has greatly changed the face of female education in Bihar. Eventually, many of these girls were eligible voters in 2015 assembly elections and were supposed to be reaching out to booths with great enthusiasm that is expected from a first-time voter.

Secondly, the decision to reserve $50 \%$ of seats in rural and urban local bodies for women have also gone a long way in empowering females of the state of Bihar. The sense of empowerment has further strengthened their belief in the democratic system and this could also be a reason for higher turnout of women in the assembly election 2015.

'Hunar' programme, specifically launched for Muslim girls by the government, is a huge success story that has also been appreciated by NITI Aayog. Under this scheme, free skills training is being imparted to poor and out-of-school Muslim girl children to ensure their socio-economic and educational development. This has also resulted in young Muslim girls getting a new sense of empowerment and it is believed that they are participating in this festival of democracy with much zeal.

It is clear from the figure 3 that in the 2010 assembly election, the highest percentage of female voting was in Mokama i.e. 54.5 percent followed by Bakhtiarpur and Fatuha in which 58.1 percent and 55.7 percent votes have been polled. The lowest percentage of female voting is in Bakhtiarpur i.e. 33 percent. The total voting percentage is highest in Fatuha followed by Bakhtiarpur and Maner. Digha and Kumhrar have voting percentage 39.3 and 36 percent respectively.

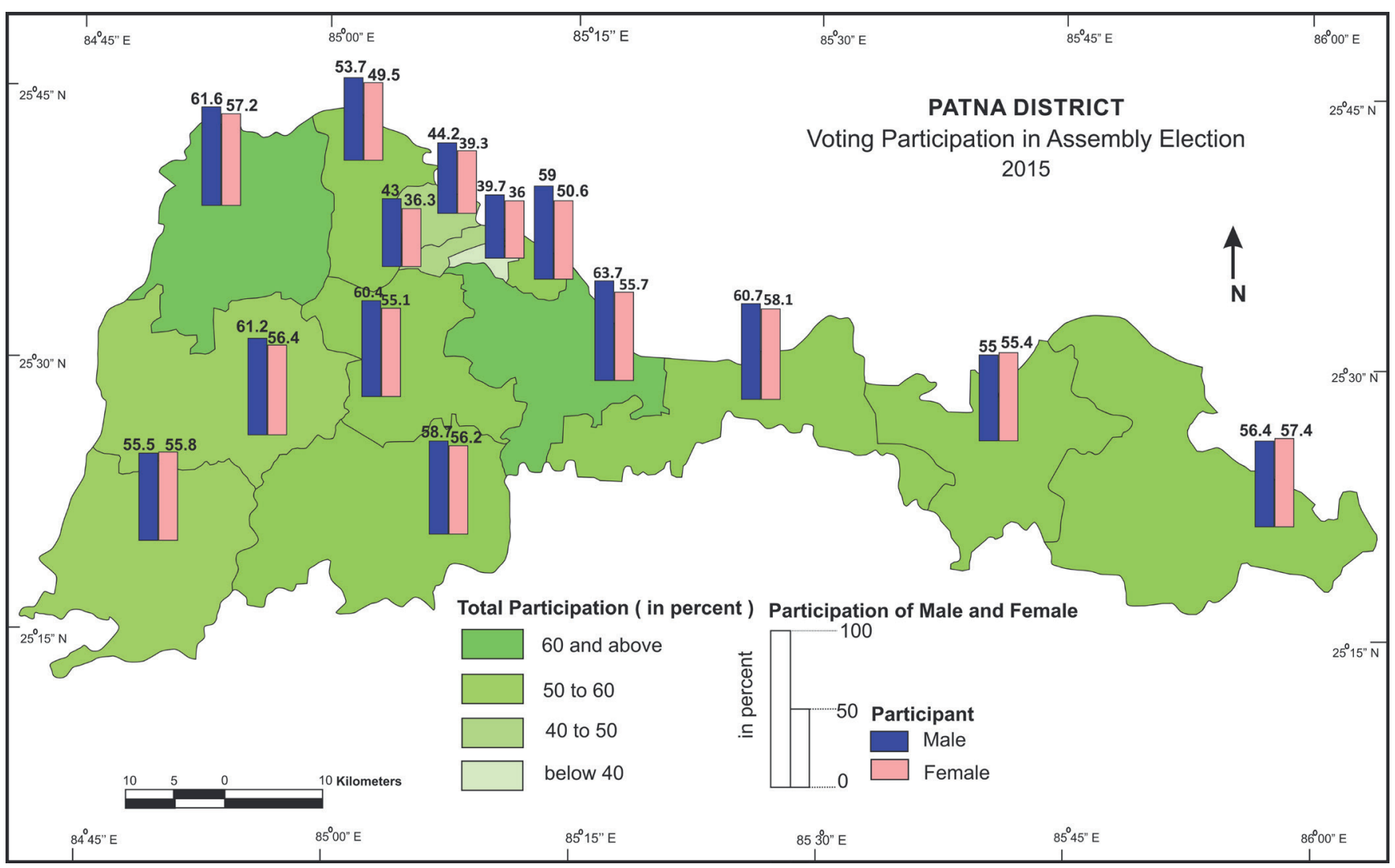

Fig. 2. Voting Participation of Women in 2015 Assembly Election in Patna District 
Mokama, Barh, Patna Sahib, Danapur, Phulwari, Masaurhi, Paliganj and Bikram have total voting in between 50 and 60 percent. In Digha, Bankipur, Kumhrar, the total voting percentage is less than 45 percent.

In 2005, two elections were held; one in the month of February and other in the months of October- November in the same year. There was a fractured verdict in February 2005 Bihar Assembly Election. Since no government could be formed in Bihar, fresh elections were held again in October and November.
In the February 2005 assembly election, the highest percentage of voting was in Bikram i.e. only 41.4 percent (figure 4) whereas in October, there was a decrease in the female voting participation.

The total voting percentage is the highest in Paliganj i.e. 46 percent (Figure 5) in October- November assembly election, which is higher by 1 percent in February assembly election. In both of the elections, the lowest total voting percentage was in Patna West i.e. 33.3 percent and 34 percent respectively.

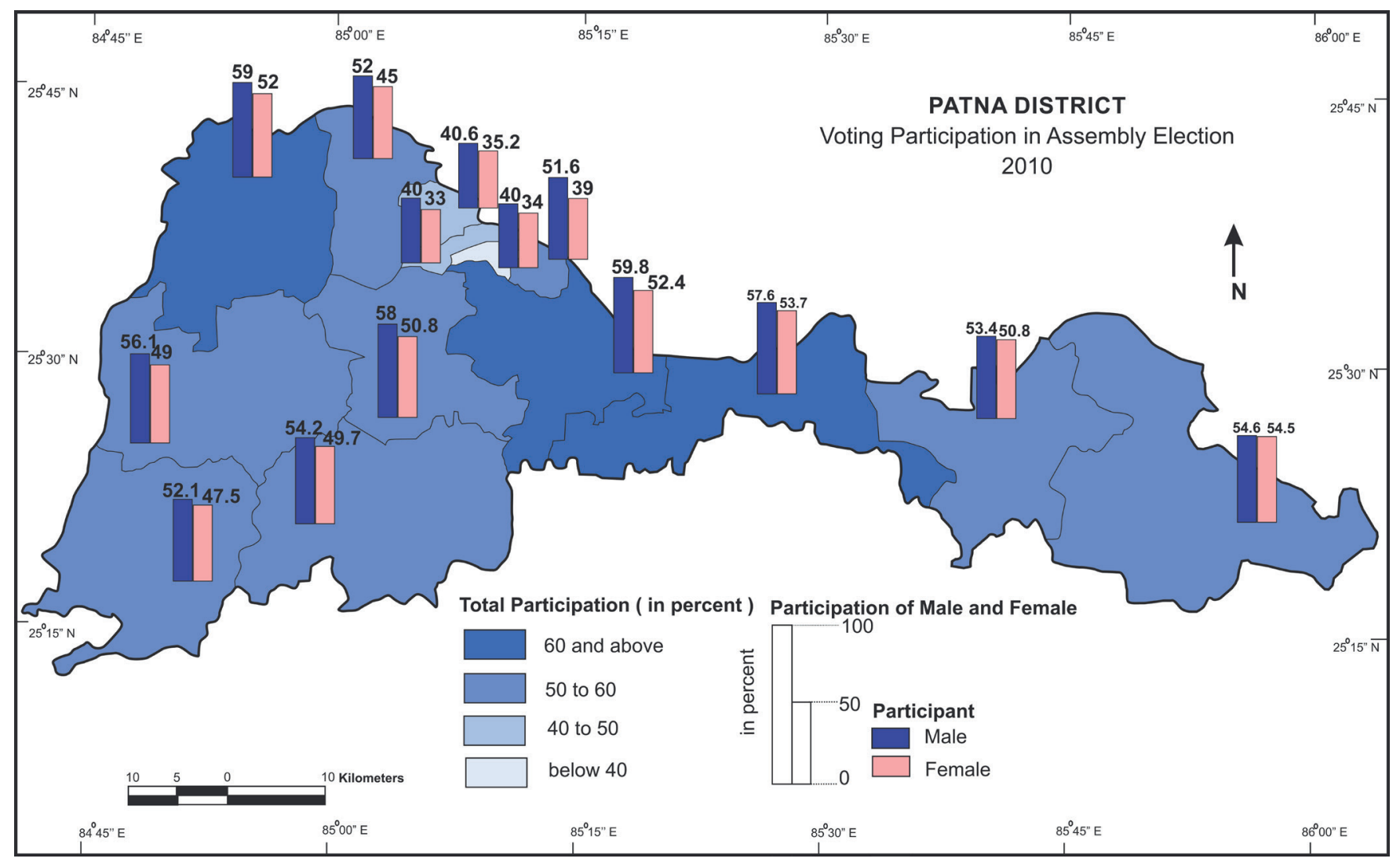

Fig. 3. Voting Participation of Women in 2010 Assembly Election in Patna District

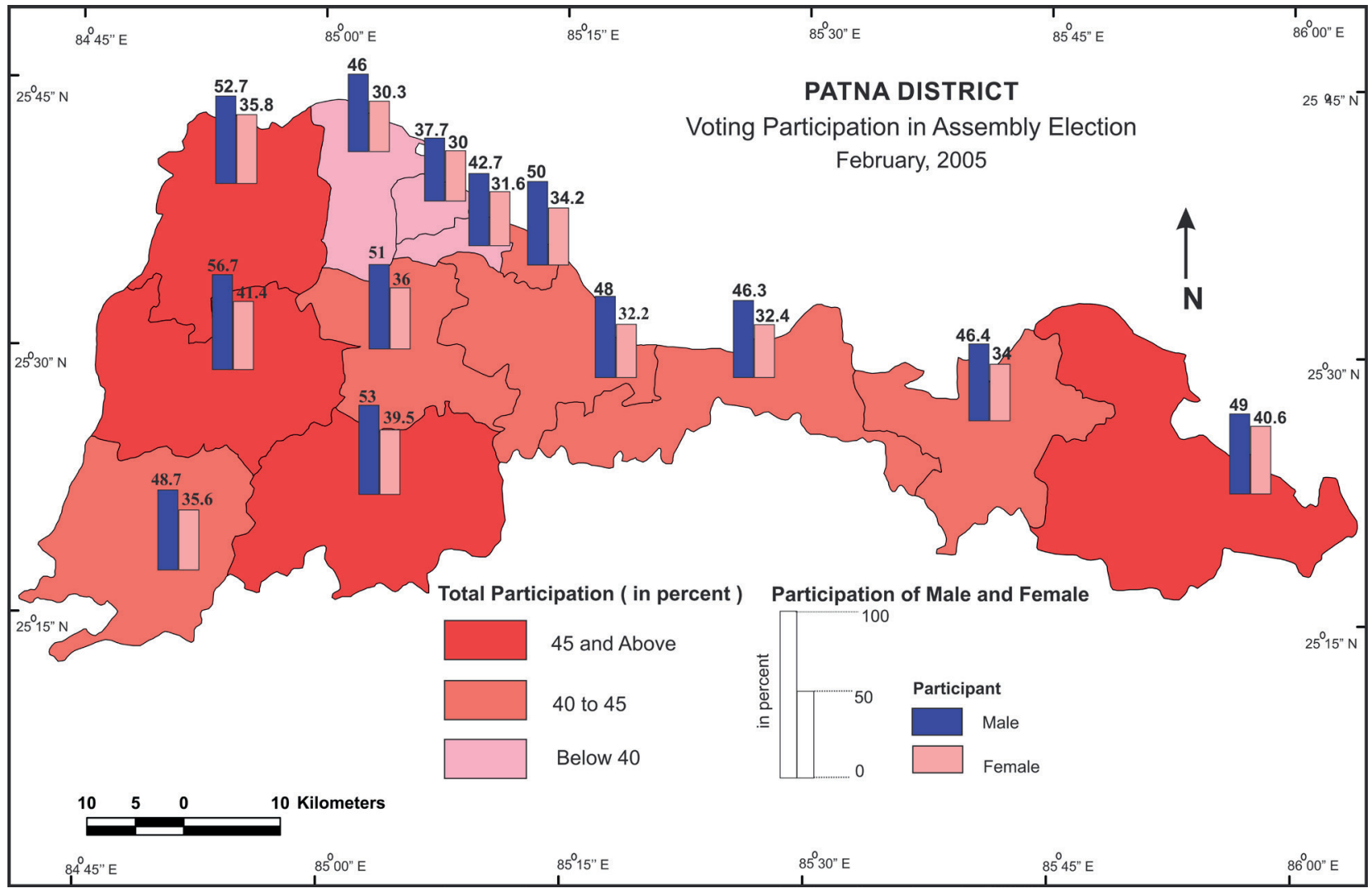

Fig. 4. Voting Participation of Women in October 2005 Assembly Election in Patna District 


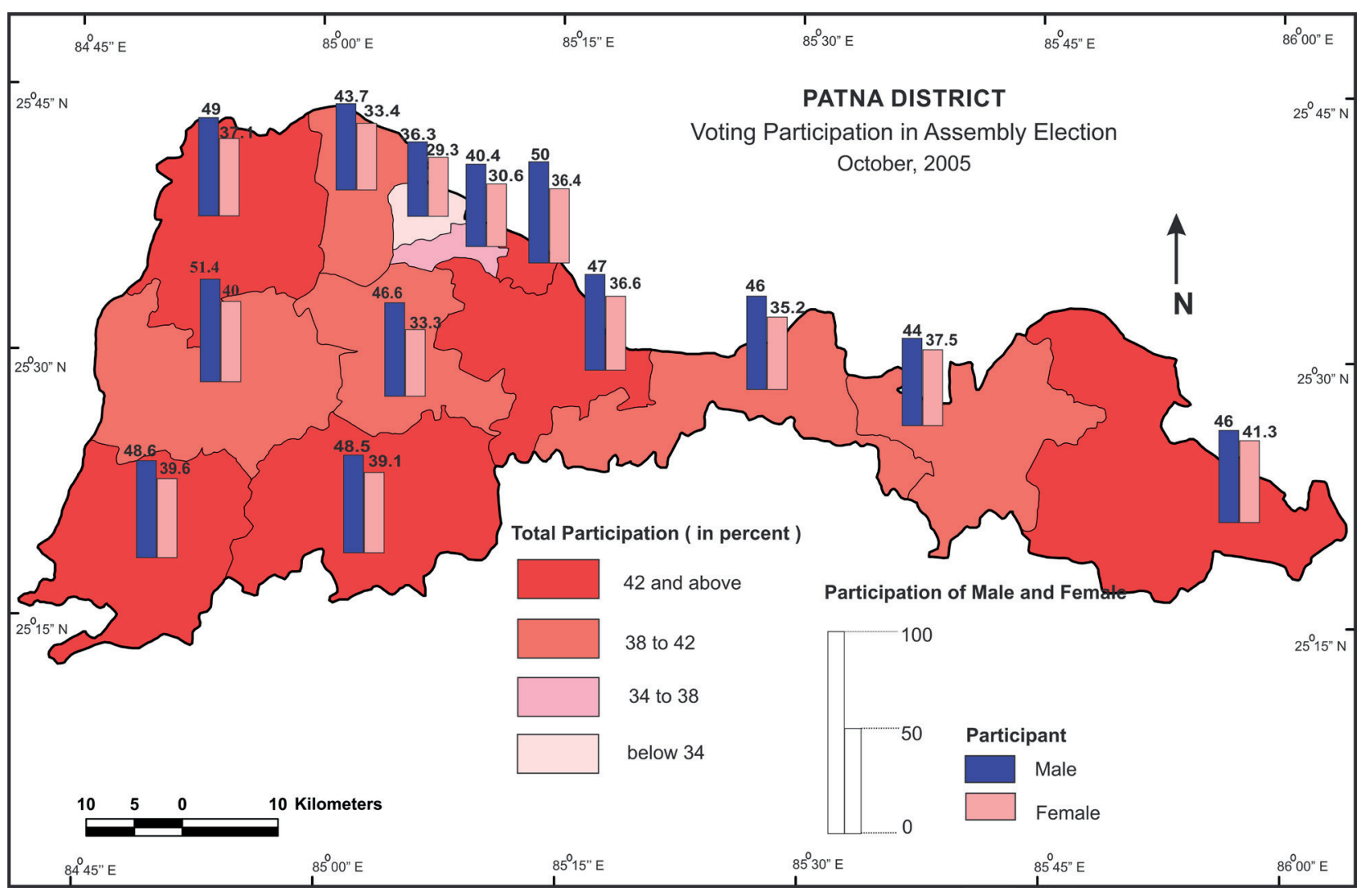

Fig. 5. Voting Participation of Women in February 2005 Assembly Election in Patna District

Female Participation in Voting in Assembly Elections of 2005, 2010 and 2015 in Patna District

The current study is an attempt to find out the role of women as voters in the political system in the study area. In Patna district, female voters comprise a significant share in elections. For the analysis of growth of female participation in electoral politics, the percentage of female voting in each assembly constituency for the assembly election of 2015, 2010, Feb 2005 and Oct-Nov 2005 are calculated. The number of constituencies were different in the assembly elections of 2010, 2015 February and October-November elections. There were fourteen assembly constituencies in 2010 and 2015 assembly elections and thirteen assembly constituencies in 2005 February and Oct-November. The temporal variation shows that there is a rising trend of women voters in each of the assembly constituencies.

Palmer (1976) has pointed out that each voter has their own ideology, political orientation, judgment and expectations which pull them to vote. It is found that the areas with a high voting percentage of male population have a higher voting percentage of female voters too.

This study found that in February 2005 election, male voters had statistically significantly higher voting percentage $(48.32 \pm 4.83)$ compared to the mean female

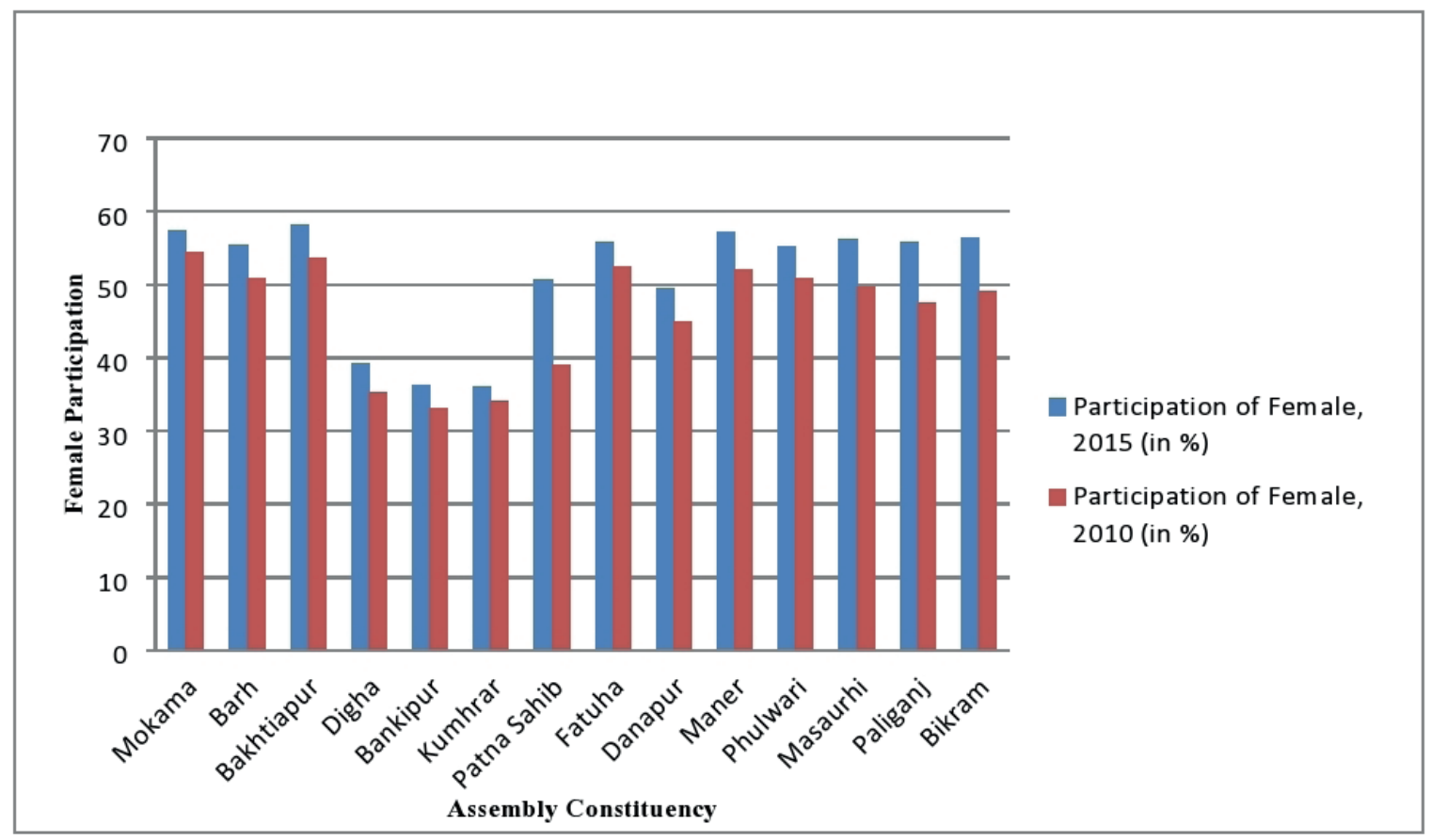

Fig. 6. Female Participation in Voting in Assembly Elections of 2010 and 2015 in Patna District 


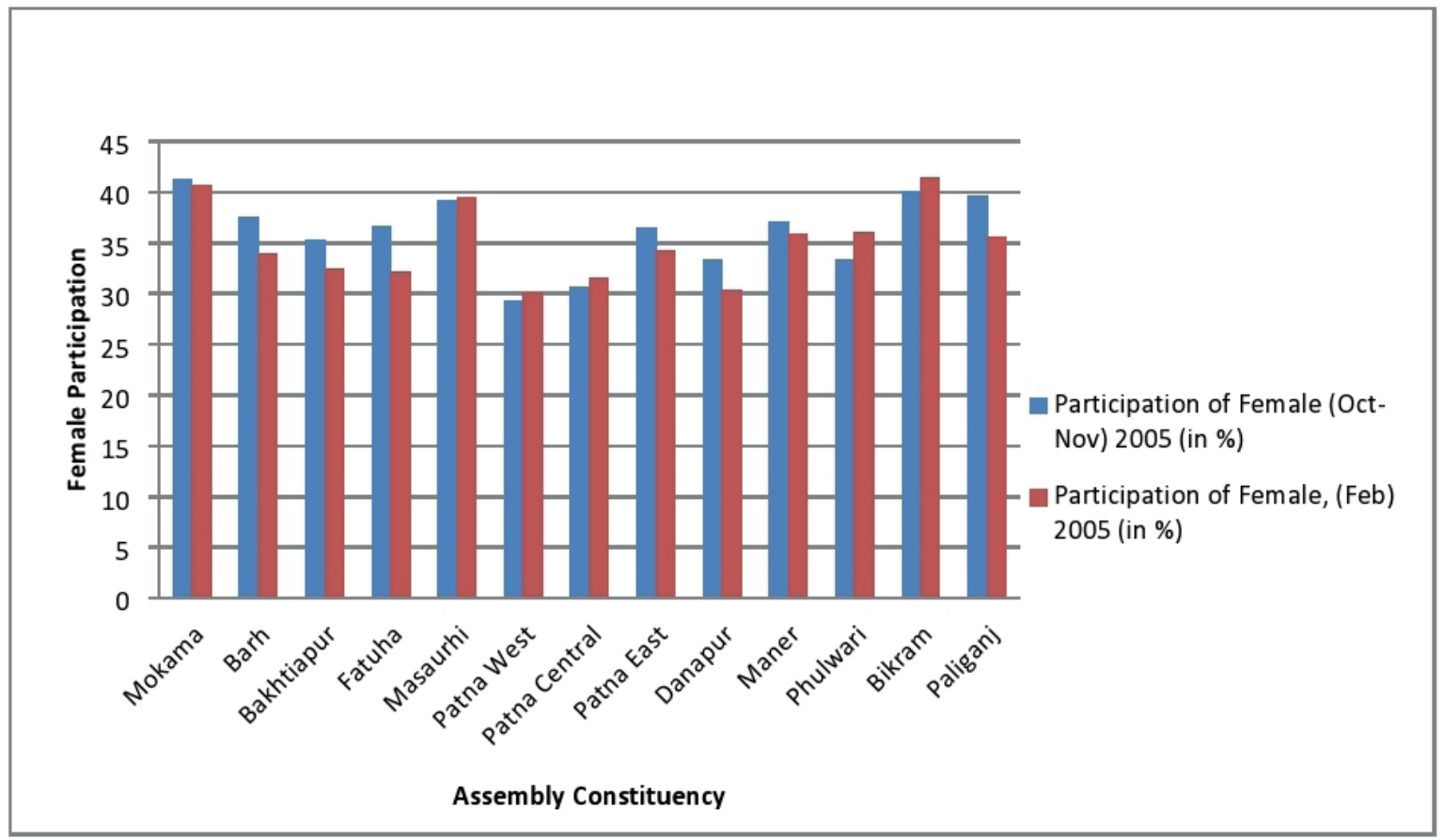

Fig. 7. Female Participation in Voting in Assembly Elections of Oct- Nov 2005 and Feb 2005 in Patna District Source: Election Commission of India

Table 1. Male and Female Voting Participation in Assembly Elections 2005, 2010, 2015 in Patna District

\begin{tabular}{|c|c|c|c|c|}
\hline Assembly Elections & Gender & Mean voting Percentage & Std. Deviation & Sig \\
\hline \multirow{2}{*}{$\begin{array}{c}\text { Assembly Election } \\
2015\end{array}$} & Male & 55.20 & 7.58 & 0.180 \\
\cline { 2 - 5 } & Female & 50.64 & 9.79 & 0.042 \\
\hline \multirow{2}{*}{\begin{tabular}{c} 
Assembly Election 2010 \\
Assembly Election (Oct) \\
\cline { 2 - 5 } 2005
\end{tabular}} & Male & 52.07 & 6.94 & $<.64$ \\
\hline & Female & 46.19 & 4.12 & $<0.0001$ \\
\hline $\begin{array}{c}\text { Assembly Election (Feb) } \\
2005\end{array}$ & Male & 45.96 & 3.64 & $<0.0001$ \\
\cline { 2 - 5 } & Female & 36.11 & 4.83 & \\
\hline
\end{tabular}

Source: Election Commission of India, Compiled by author

voting percentage $(34.89 \pm 3.76), \mathrm{t}(24)=7.920, \mathrm{p}<0.0001$ (Table 1). A significant 9.85 percent of higher voting percentage is observed among male voters (45.96 \pm 4.12$)$ compared to female (36.11 \pm 3.64$), p<0.0001$ (Table 1). No significant difference in voting percentage is observed between male and female in 2010 and 2015 assembly elections in Patna district of India.

The mean voting percentage for men in 2010 election is (52.07 \pm 6.94$)$ compared to (46.19 \pm 7.64$), p=0.042$ and in 2015 election for men voting percentage is (55.20 \pm 7.58) compared to (50.64 \pm 9.79$), p=0.180$.

\section{Association between Literacy and Voting}

A person aged seven and above who can both read and write with understanding in any language, is treated as literate (Census of India 2011). Bihar has a literacy rate of 63.82 percent with male literacy of 73.39 percent and female literacy rate of 53.33 percent, which is lowest in the country. In Patna district, the male literacy rate is 72.57 percent while female literacy rate is 51.04 percent. The literacy rate of sample population corresponds with the State figure. The literacy rate among female respondents is found as 52.9 percent (522/986) whereas 47.1 percent were illiterate. The literacy rate of urban and semi- urban regions is higher than the rural region. It is noticed during the field survey that illiterate voters are not aware about the political system of the country and they don't not have proper knowledge about the candidates. "Mass illiteracy has been a factor of voting behaviour in India. It is because of this weakness of the people that political parties, communal groups and militancy outfits are in position to exploit the sentiments of the votes of the illiterates constitute a big proportion of the votes polled and hence they play a big role in determining the outcomes of elections» (Akhter and Sheikh 2014).

Research done in many countries suggest that education and social status of individuals are major determinants of political participation (Nor, Gapor and Bakar 2011).In the study area both literate and illiterate groups are conscious about their voting rights. However, it was found that 97.8 percent of all illiterate population is registered voters and regular compared to 93.7 percent of literate population respectively. In both literate and illiterate groups, it was found that socio-economic development and willingness to practice voting right is the main reason behind casting their vote. 
Table 2. Association between Literacy with Voting

\begin{tabular}{|c|c|c|c|c|c|c|}
\hline \multirow{2}{*}{\multicolumn{2}{|c|}{ Association of Voting }} & Illiterate & Literate & Total & Chi Value & sig. \\
\hline & & $464(47.1 \%)$ & $522(52.9 \%$ & $986(100.0 \%)$ & & \\
\hline \multirow{2}{*}{\multicolumn{2}{|c|}{$\begin{array}{l}\text { Not registered Voter } \\
\text { Registered Voter }\end{array}$}} & $10(2.2 \%)$ & $33(6.3 \%)$ & $43(4.4 \%)$ & \multirow{2}{*}{10.225} & \multirow{2}{*}{0.001} \\
\hline & & $454(97.8 \%)$ & $489(93.7 \%)$ & $943(95.6 \%)$ & & \\
\hline \multirow{2}{*}{\multicolumn{2}{|c|}{$\begin{array}{l}\text { Irregular Voter } \\
\text { Regular Voter }\end{array}$}} & $117(25.2 \%)$ & $137(26.2 \%)$ & $254(25.8 \%)$ & \multirow{2}{*}{0.136} & \multirow{2}{*}{0.712} \\
\hline & & $347(74.8 \%)$ & $385(73.8 \%)$ & $732(74.2 \%)$ & & \\
\hline \multirow[t]{5}{*}{ Voting Motivation } & Motivation & $99(21.3 \%)$ & $32(6.1 \%)$ & $131(13.3 \%)$ & \multirow{5}{*}{52.874} & \multirow{5}{*}{$<0.0001$} \\
\hline & Practicing Voting Right & $142(30.6 \%)$ & $196(37.5 \%)$ & $338(34.3 \%)$ & & \\
\hline & Development & $204(44 \%)$ & $257(49.2 \%)$ & $461(46.8 \%)$ & & \\
\hline & Social Security & $7(1.5 \%)$ & $8(1.5 \%)$ & $15(1.5 \%)$ & & \\
\hline & Others & $12(2.6 \%)$ & $29(5.6 \%)$ & $41(4.2 \%)$ & & \\
\hline
\end{tabular}

Source: Sample Survey, 2018

Voting is the easiest way to raise your voice. People must have adequate information about communicating their preferences to elected representatives. If they did not know about their political preferences they would have no motivation to engage in political deliberation (Bhatia 2013). Voting motivation varies from person to person; some people are motivated by the fact that voting is their civic duty, while others may vote for development, and social security.

Nowadays women are casting their vote more frequently, and in greater numbers, which is a remarkable turn of event in a deeply patriarchal, conservative society. Motivational Constraints

According to Banerjee (2017), elections are not only cultural but also a moral event. People come to vote even though one vote is immensely small, but it has immense value. The quality of democratic choice critically depends on the voter's motivation. If voters are motivated, voting may result in smart choices because of information aggregation.

A total of 40.1 percent (395/986) the participant has faced motivational constraints compared to 59.9 percent who did not face any motivational constraints. Motivational constraints include lack of education, not liking the candidates, no faith in political parties, dissatisfaction from the government and political apathy etc.

Figure 8 show that 30 percent of women from rural areas, 47.4 percent from semi-urban and 53.5 percent from urban areas reported that they faced motivational constraints. 48.5 percent in Mokama, 29.7 percent in Barh, 7.8 percent in Bakhtiarpur, 44 percent in Paliganj, 47.8 percent in Bihta, 11.5 percent in Bikram and 53.9 percent from Bankipur stated motivational constraints.

\section{Situational Constraints}

It is one of the factors which accounts for differences in voter participation from place to place. Among the respondents, 48.6 percent (479/986) responded as they face situational constraints such as distance of home from polling booth, long queue, domestic responsibilities, and poor health condition during elections, and not living in the home town etc. Bihar, in past, has witnessed intimidation of vulnerable sections for voting in favour of particular political establishments (Yadav 2004).

Sometimes sporadic violence on the polling day prevents the people from casting their vote. 51.4 percent who did not face situational constraints during the elections. According to figure 9, 55 percent from urban areas, 54.9 percent from semi- urban areas and 42.5 percent in rural areas faced situational constraints. 55.8 percent from Mokama, 34 percent from Bakhtiarpur, 56.4 percent from Maner and 47.4 percent from Digha faced situational constraints during voting. It is reported that longer the line at the polling booth, the greater the likelihood that voters will become frustrated and leave before voting. Secondly, distance from polling booths discourages voter turnout in the study area.

\section{Challenges of Electoral Empowerment of Women}

The biggest challenge is the less representation of women in political parties. Women are still struggling for increased political participation (Alam 2015). Bihar is a least literate state in the country as per Census of India, 2011. The literacy rate among the women is $53.3 \%$. The level of awareness among electors is closely associated with level

Table 3. Motivational and Situational Constraints

\begin{tabular}{|c|c|c|c|c|c|}
\hline & Illiterate & Literate & Total & Chi Value & Sig. \\
\hline \multirow{2}{*}{$\begin{array}{l}\text { Not faced motivational constraints } \\
\text { Faced motivational constraints }\end{array}$} & $301(64.9 \%)$ & $290(55.6 \%)$ & $591(59.9 \%)$ & \multirow[t]{2}{*}{8.877} & \multirow{2}{*}{0.003} \\
\hline & $163(35.1 \%)$ & $232(44.4 \%)$ & $395(40.1 \%)$ & & \\
\hline Not faced situational constraints & $244(52.6 \%)$ & $263(50.4 \%)$ & $507(51.4 \%)$ & \multirow{2}{*}{0.477} & \multirow{2}{*}{0.49} \\
\hline Faced situational constraints & $220(47.4 \%)$ & $259(49.6 \%)$ & $479(48.6 \%)$ & & \\
\hline
\end{tabular}

Source: Sample Survey, 2018 


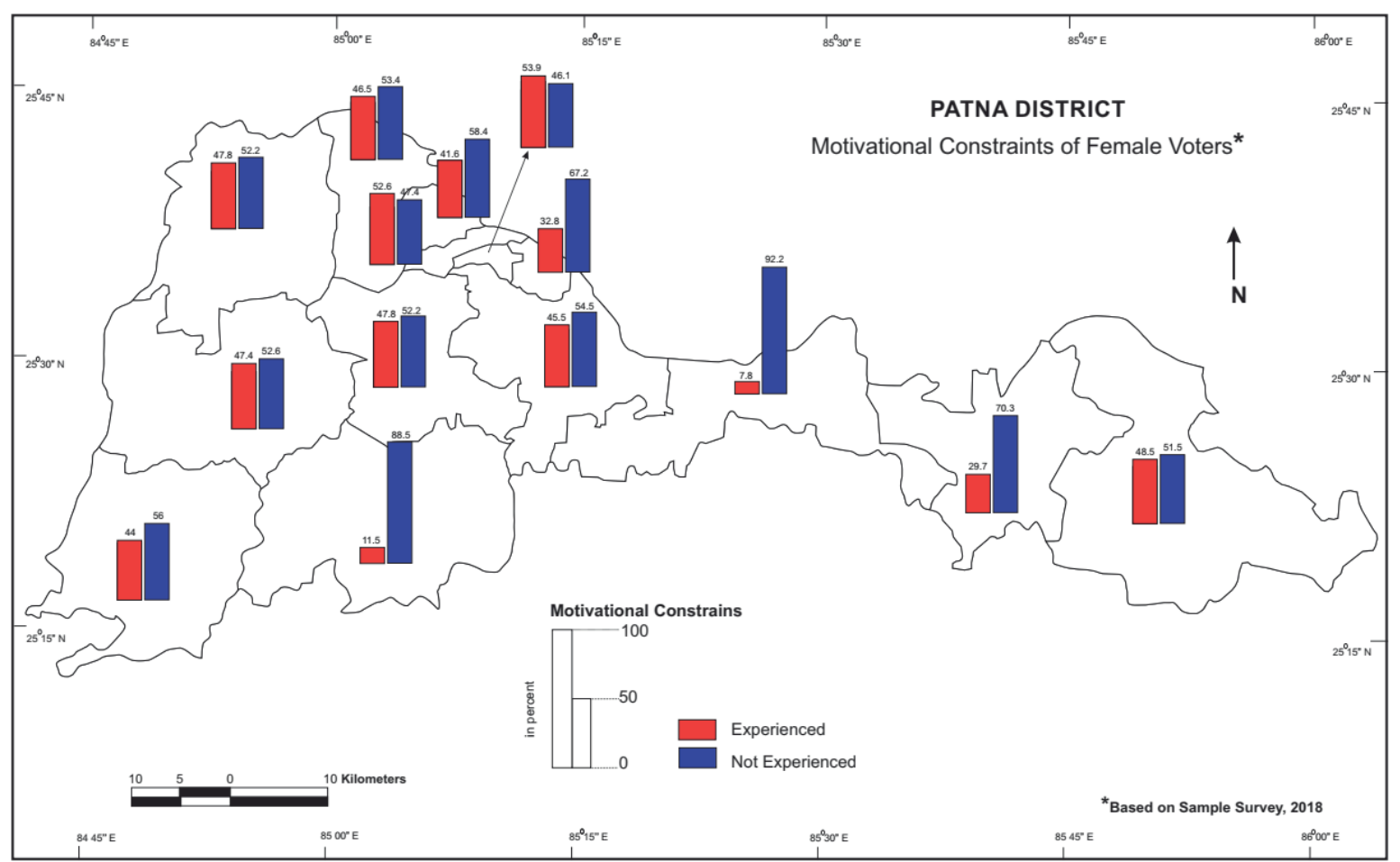

Fig. 8. Motivational Constraints of Female Voters in Patna District

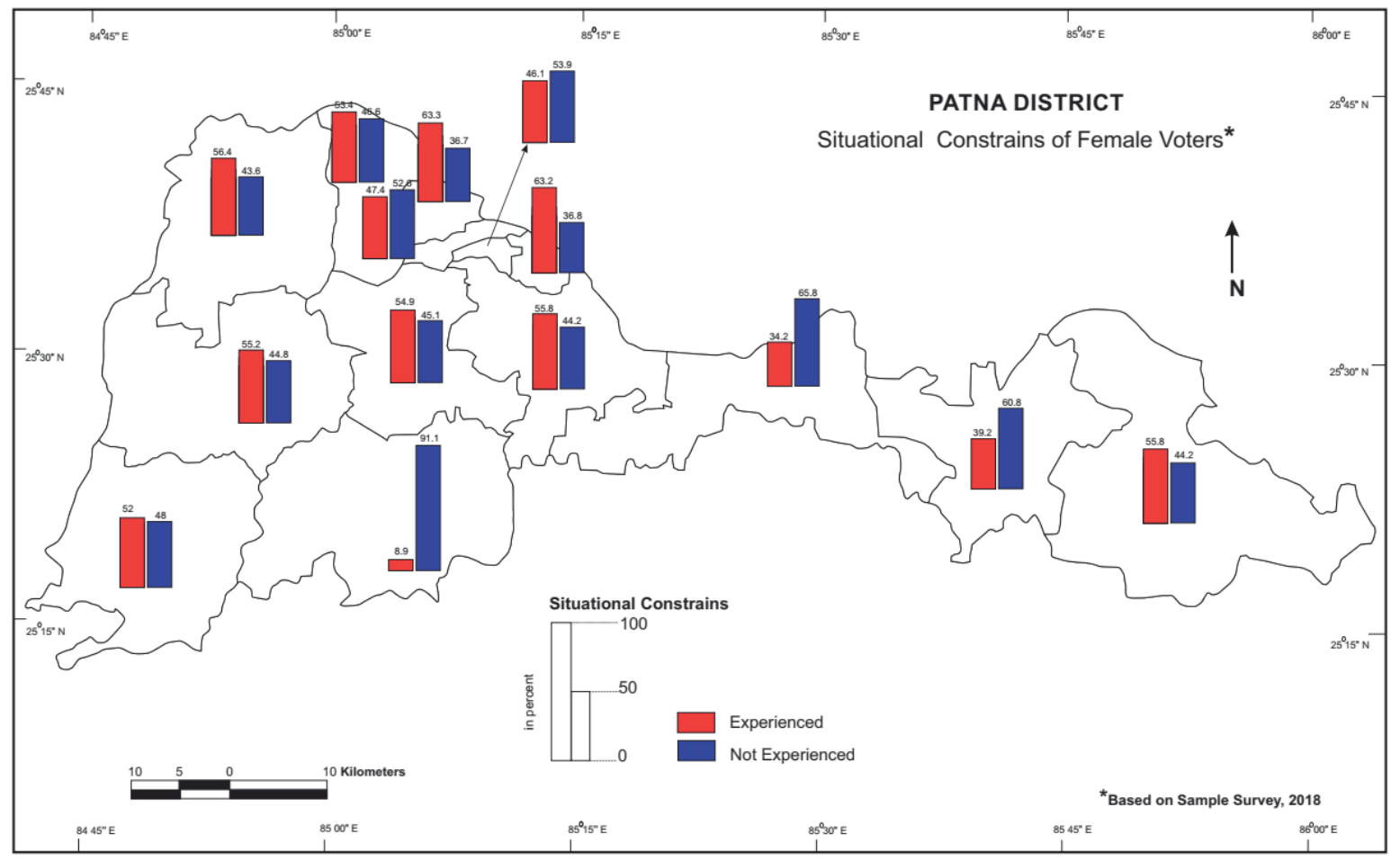

Fig. 9. Situational Constraints of Female Voters in Patna District

of education (Dahlerup D. 2005). Nevertheless Bihar is having a patriarchal society, where women are often seen as subordinate and inferior to man.

Apart from this there is a big gap in the registration of women in electoral rolls. Enrollment of women is not given priority due to the lower status of women in the society. The electoral roll gender ratio is not in consonance with the census gender ratio. The census gender is 918 whereas the electoral roll gender ratio is 875 in the 2015 assembly election. Cultural inhibition is also included in the challenges of women's electoral empowerment. Women do not come out of their home without the permission of the head of the family. In general, women still want a male member to go outside or to the polling station.

\section{CONCLUSION}

The above discussion summarizes that the active political participation of women in politics is very important to achieve United Nations Sustainable Development Goal Five. The research work tries to explain the electoral empowerment of women with reference to Patna District, more specifically to examine spatio temporal pattern of women's participation in assembly elections of 2005, 2010 and 2015. Increase in the temporal pattern of women's participation in elections is evident from the study; however, the growth rate of the women voting percentage is less than that of men. Increase in the voting shows that women in the study area are getting politically empowered. Bihar scored 40 out of 100 in SDG 5 with rank 17 among 
all the states. Amid all the 17 Sustainable Development Goals (SDGs) laid out by the United Nations, SDG 5, which stands for gender equality has been the toughest to fight and establish in India. Except Chandigarh, Sikkim, Kerala, Andaman and Nicobar Islands - all other states lie in the red zone or the «aspirant zone» according to the latest reports by SDG India Index Baseline Report (2019).Women empowerment and gender equality is very essential for human development so it must be integrated with all the SDGs.

\section{REFERENCES}

Kumar N., Raghunathan K., Arrieta A., Jilani A., Chakrabarti S., Menon P. and Quisumbing A.R. (2019). Social networks, mobility, and political participation: The potential for women's self-help groups to improve access and use of public entitlement schemes in India. World development, 114, 28-41.

Adhikari S. (2005). Political Geography, Rawat Publications, Jaipur and New Delhi.

Akhter Z. and Sheikh Y.A. (2014). Determinants of Voting Behaviour in India: Theoretical Perspective. Public Policy and Administration Research, 4(8), 104-108.

Alam S. (2015). Participation of Women in Indian Politics and the Role of Media. International Journal of Advanced Research in Management and Social Sciences, 4(1), 77-83.

Ali S. and Lin C. (2013). Why People Vote: Ethical Motives and Social Incentives. American Economic Journal: Microeconomics, $5(2), 73-98$. Amani K.Z. (1970). Election in Haryana: A study in Electoral Geography, The Geographer, 17, 27-40.

Banerjee M. (2017). Why India Votes? Routledge, New Delhi and Oxon.

Begum S. (2015). Political Participation of Women: Some Issues and Challenges, International Journal of Applied Research, 11(1), 480-486. Bhatia U. (2013). Deliberative democracy and illiteracy: Exploring a theoretical gap. Journal of Public Deliberation, 9(2), 80-95.

Carole S. (2007). Female Political Leadership in India, Commonwealth and Comparative Politics, 45(3), 253-277.

Dahlerup D. (2005). Strategies to Enhance Women's Political Representation in Different Electoral Systems. Gender, Governance and Democracy, Manila: Isis

Dasgupta B. and Morris W.H. (1969). India's. Political Arenas: Interim Report on and Ecological Perspective, Asian survey, 96, $399-424$.

Datta A. and Rustagi Preet. (2012). Status of women in Bihar: Exploring transformation in work and gender relations. International

Feminist Journal of Politics, 88, 66-87.

Deshpande and Rajeshwari (2004). How Gendered was Women's Participation Women in Election 2004? Economic and Political Weekly, 39(51), 5431-5436.

Devi and Lakshmi (2005). Political Empowerment of Women in Indian Legislature: A Study, The Indian Journal of Political Science, 66(1), 75-92.

Dikshit H.H. and Giri S.K. (1983). Changing Spatial Pattern of the Parliamentary Constituencies in India from 1951-1976, Geographical Review of India, 45, 83-95.

Dikshit R.D. and S. Singh (1993). Friends and Neighbours Influence in Indian Elections: A Case Study of Rural Voting in Sonipat Parliamentary Constituency (Haryana), Asian Profile, 21, 483-493.

Fadia K. (2014). Women's Empowerment through Political Participation in India, International Journal of public Administration, 60(3), 537-548.

Falcao V. (2009). Urban Patterns of Voting and Party Choices. Economic and Political Weekly, 44(39), 99-101.

Hussain M. and Mir A.M. (1984). The Assembly Election on Jammu and Kashmir: A Study in Spatial Voting Behaviour in 1983, National

Geographical Journal of India, 30, 53-62.

Kashyap S.C. (2019). Constitution of India - A Handbook for Students. Vitasta Publishing, New Delhi.

Khanna M. (2009). Political Participation of Women in India. The Indian Journal of Political Science, 70(1), 55-64.

Mamta (2011). The Indian Journal of Political Science, 72(2), 614-616.

Muneshwar Yadav (2004). Politics from Below. Economic and Political Weekly, 39(51), 5510-5513.

Negi M.M.S (2011). Voting Attitude of Women in Uttarakhand with Special Reference to Garhwal. The Indian Journal of Political Science,

$72(3), 803-818$.

Nelson B. and Chowdhary N. (Eds) (1994). Women and Politics Worldwide, London, Yale University Press.

Niti Aayog (2019). SDG India Index and Dash Board 2019-20, Niti Aayog, New Delhi.

Nor W.A., Gapor S.A. and Bakar M.Z.A and Harun Z. (2011). Some Socio-Demographic of Political Participation, IPEDR, 20(2011), 69-73.

Palmer ND (1976). Elections and Political Development. The South Asian experience, Vikas Publishing House, Delhi.

Rai P. (2017). Women's Participation in Electoral Politics in India: Silent Feminisation, South Asia Research, 37(1), 58-77.

Rai Praveen (2011).'Electoral Participation of Women in India: Key Determinants and Barriers', Economic and Political Weekly, $46(3), 47-55$.

Sharma J.C. (1982). The Indian Context and Geographical Study of Voting Behaviour, Indian Geographical Studies, 19, 9-16.

Sinha K. (1985). Measuring Party Competition: A New Approach, Geographical Review of India, 47, 1-6.

Statistical Reports of Assembly Elections 2005, 2010 and 2015, Election Department, Bihar, Patna.

Verma R.K. and Yadav G.K. (1996). Women in Bihar Politics'Economic and Political Weekly, 22, 935-937.

Weblinks: Inter-Parliamentary Union (2016). http://www.ipu. org/wmn-e/classif.htm [Accessed on 20 January 2021].

Election Commission of India (2015). https://eci.gov.in/

Census of India (2011). http://www.censusindia.gov. In/2011census/

United Nations (2015). https://www.un.org/sustainabledevelopment/gender-equality/ 